\title{
HIV/AIDS og risikoen for selvmordsatferd
}

\author{
Ved Lourens Schlebusch
}

\section{Denne artikkelen gir en beskrivelse av hiv/aids-epidemien og risikofaktorer for selvmordsatferd forbundet med den. Artikkelen gir også anbefalinger for håndtering og forebygging, og stiller spørsmål som det må forskes videre på.}

\section{Innledning}

Hiv/aids er et av de største helseproblemene i verden. Siden de første aidstilfellene ble påvist i 1981, har cirka 65 millioner mennesker over hele verden blitt smittet av hiv og mer enn 25 millioner har d $\varnothing \mathrm{dd}$ av aids. Bare i 2005 døde 2,8 millioner mennesker av aids og over 4 millioner ble smittet av hiv, og de fleste av de 38,6 millionene som levde med hiv/aids hadde ikke tidligere visst at de var smittet. Bare cirka $20 \%$ av hivsmittede i lav-og mellominntektsland får tilbud om livsforlengende antiretroviral (ARV) behandling (UNAIDS, 2006).

Rundt $70 \%$ av alle selvmord skjer i utviklingsland, hvor også hiv/aids-epidemien herjer. Noen av de verst rammede regionene finner vi i Afrika sør for Sahara, der beregninger (UNAIDS, 2006) viser at omkring 2 millioner mennesker $\mathrm{d} \varnothing \mathrm{de}$ av aids i 2005, mens cirka 2,7 millioner ble smittet og 24,5 millioner levde med hiv/aids, cirka $59 \%$ av disse var kvinner. I 2005 var det kun cirka $17 \%$ som fikk ARV-behandling, omtrent 2 millioner barn under 15 år levde med hiv/aids (cirka $90 \%$ av alle smittede barn) og nesten $10 \%$ av alle barn (cirka 12 millioner) hadde mistet en av eller begge foreldrene sine på grunn av aids. I 2005 bodde nesten $1 / 3$ av de hivsmittede i verden i det sørlige Afrika, mens cirka $43 \%$ av alle smittede barn under 15 år og $52 \%$ av alle smittede kvinner hørte hjemme der.

I 2005 var det i Sør-Afrika anslagsvis 5,5 millioner mennesker og nesten en av tre gravide kvinner som kom til oppfølging ved offentlige helsestasjoner, som var smittet (UNAIDS, 2006). Dette har fått store følger for både husholdninger og næringsliv (South African Health Review, 2003/2004). Provinsen KwaZuluNatal (der min forskning på selvmordsatferd og hiv/aids har funnet sted) har den høyeste forekomsten av hivsmitte i SørAfrika (Lindegger \& Wood, 1995; Schlebusch, 2005). I 2004 var det der flest smittede i aldersgruppen 25-29 år (52,2 \%) og i gruppen 30-34 år (49,5 \%), fulgt av aldersgruppen 20-24 år (44,3 \%) og grup- pen under 20 år (29,5\%). Utbredelsen blant gravide kvinner som gikk til kontroll på helsestasjoner, var så høy som 40,53 \% (Schlebusch, 2005; Schlebusch $\&$ Noor Mohamed, 2004; South African Health Review, 2003/2004).

\section{Høyrisikoperioder}

Sterke svingninger i stemningsleiet, angstlidelser, stoffmisbruk og bruk av angstdempende medikamenter synes å være klart vanligere blant hivsmittede enn i befolkningen for $\varnothing$ vrig (Anderson, 2005). Angstdempende medikamenter og ARV-medisinering kan ha neuropsykiatriske bivirkninger (Treisman \& Kaplin, 2002), og tidligere psykiske lidelser kan innvirke på en persons evne til å takle hiv/aids (Schlebusch, 2005). Følgelig viste tidlige studier opptil 36 ganger større risiko for selvmordsatferd blant hivsmittede enn i befolkningen for $\varnothing$ vrig, men bedre oppfølging har bedret situasjonen noe (Anderson, 2005; Marzuk et al., 1997). Tallene varierer imidlertid, særlig i utviklingsland (Schlebusch, 2005). For eksempel viste en unders $\varnothing$ kelse som nylig ble gjennomf $\varnothing$ rt i S $\varnothing$ r-Afrika (Schlebusch $\&$ Noor Mohamed, 2005), at $16 \%$ av dem som var innlagt på sykehus på grunn av selvmordshandlinger hadde hiv/aids. En annen unders $\varnothing$ kelse (Meel, 2003) antyder en sammenheng mellom stigende selvmordsrater og den $\varnothing$ kende utbredelsen av hiv/aids.

Forh øyet risiko for selvmordsatferd forekommer i forbindelse med hivtesting ( $\varnothing \varnothing \mathrm{r}$ resultatet er kjent), når man får vite at man er hivpositiv (særlig i de første tre til seks månedene etterpå), når man har utviklet aids, og i sykdommens siste stadier, som ofte er kjennetegnet av fysisk og psykisk svekkelse (Gala et al., 1992; Kelly, Raphael \& Judd, 1998; Perry, Jacobsberg \& Fishman, 1990; Schlebusch, 2005). I en unders $\varnothing$ kelse gjorde nesten halvparten av de hivsmittede selvmordsfors $\varnothing \mathrm{k}$ innen tre måneder fra de fikk vite at de var hivpositive, og cirka to tredeler gjorde minst ett fors $\varnothing \mathrm{k}$ i l $\varnothing$ pet av det f $\varnothing$ rste året (Rundell, Kyle \& Brown, 1992).
Selvmordsatferd som opptrer i de tidlige stadiene av en hivinfeksjon hos mennesker som fortsatt er relativt friske, er blitt beskrevet som "forhindringsselvmord" et fors $\varnothing \mathrm{k}$ på å unnslippe de skremmende utsiktene til et liv med aids (Beckerman, 1995; Schlebusch, 2005; Siegel \& Meyer, 1999).

\section{Andre risikofaktorer}

En historie med psykiske lidelser (særlig depresjon, personlighetsforstyrrelser og stoffmisbruk) og tidligere selvmordsatferd har vært sett på som risikofaktorer, på samme måte som arbeidsrelatert stress og nedsatt evne til stressmestring (Kelly, Raphael \& Judd, 1998; Noor Mohamed \& Karim, 2000; O’Dowd, Biderman \& McKegney, 1993; Rundell, Kyle \& Brown, 1992;

Schlebusch, 2005).

Problemer i forhold til andre mennesker (både intime, yrkesmessige og sosiale forhold) kan bli overveldende, i likhet med frykten for at partneren skal være utro, noe som er koblet til redselen for hivsmitte (Anderson, 2005; Schlebusch, 2005). I forbindelse med et mord/selvmord i KwaZulu-Natal i 2005 ble det fortalt at en mann drepte kona si og to medlemmer av hennes familie f $\varnothing \mathrm{r}$ han tok sitt eget liv på grunn av at hun nektet å ha sex med ham fordi hun fryktet at han var hivpositiv (Ndaba, 2005). Bevisste fors $\varnothing \mathrm{k}$ på å bli hivsmittet har vært sett på som en form for selvmordsatferd på samme måte som $\varnothing$ kning i risikofylt seksuell atferd hos homofile menn som har mistet nære personer på grunn av aids (Catalan, 2000). Sørafrikanske studier (Schlebusch, 2005; Schlebusch \& Noor Mohamed, 2005) har påvist at selv om sykehuspasienter med hiv/aids-relaterte selvmordsfors $\varnothing \mathrm{k}$ bak seg var villige til å snakke om selvmordsfors $\varnothing$ ket, var det svært få som frivillig fortalte at de var hivsmittet (til tross for at dette stod i journalen deres) av frykt for den negative effekten dette kunne få for livet deres. Utvalget i den sistnevnte unders $\varnothing$ kelsen $(\mathrm{N}=109)$ bestod av $26 \%$ menn og $74 \%$ kvinner med en gjennomsnittsalder på 38,5 år. Generelt var over $80 \%$ av pasientene i unders $\varnothing$ kel- 
sen deprimerte, og i hele utvalget var de følgende psykososiale problemene tydelige (pasientene oppgav mer enn én grunn hver): Mangelfull tilgang til helsetjenester (22\%), manglende sosial st $\varnothing t t e(71 \%)$, frykt for stigmatisering (54\%), stress på grunn av utvikling av aids (24\%), sosio$\varnothing$ konomiske problemer slik som manglende bosted og arbeidsledighet (44\%), samt det å bli tvunget til å si opp eller å bli oppsagt fra arbeidet sitt på grunn av sin hiv/aids-status (10\%). I unders $\varnothing$ kelsesgruppen med hiv/aids-relaterte selvmordsfors $\varnothing \mathrm{k}$ var $30 \%$ seronegative kvinner som var bekymret over partnerens utroskap, mens $40 \%$ av de hivpositive mennene beskyldte sine kvinnelige partnere for å ha smittet dem.

De som lever med hiv/aids, opplever spesielle stressfaktorer. Her skal vi nevne noen av disse faktorene. De smittede blir assosiert med andre stigmatiserte grupper - for eksempel rusmisbrukere. De står overfor store livsløpsendringer på grunn av sykdommen, noe som spesielt gjelder de unge fordi sykdommen er uhelbredelig og tvinger fram en livslang atferdsendring. De blir opptatt av fysiske symptomer. De vet at de i de siste stadiene av sykdommen kan få kognitive, neuropsykiatriske og fysiske funksjonshemninger. Det oppstår frykt knyttet til smitteaspektet ved sykdommen. Denne frykten kan føre til selvpålagt sosial tilbaketrekning eller fors $\varnothing \mathrm{k}$ fra dem som ikke er smittet, på å unngå sosial og fysisk kontakt med dem som er smittet, slik at de sistnevnte føler seg utstøtt. I tillegg kan hivsmittede bli stresset av samfunnets misbilligelse basert på moralske holdninger, av å bli klandret fordi de fikk sykdommen, av usikkerhet rundt sykdomsutviklingen, av skyldfølelse og selvhat, samt av problemer de opplever med rådgivning f $\varnothing \mathrm{r}$ og etter hivtesting (Noor Mohamed \& Karim, 2000; Schlebusch, 2005).

Særlig opplever kvinner en hel rekke hivrelaterte stressfaktorer (Anderson, 2005). Enkelte kulturer i Afrika ser f.eks. på hiv/ aids som en mystisk kraft, noe som kan gjøre at de takler dårligere å leve med sykdommen og skape tro på "uflaks", "ond skjebne", "utrivelighet" med det resultat at personen blir mislikt av andre (Noor Mohamed \& Karim, 2000). I slike situasjoner blir den hivsmittede personen sosi- alt isolert og må snakke lavt og fort eller bare når det er strengt nødvendig. Alt dette gir personen en opplevelse av å være "sosialt død". Kvinner, som har større risiko for å bli smittet enn menn, snakker ofte om at de lever med en " $\varnothing$ delagt identitet" og at de ikke er "fresh". Når de skal forholde seg til stigmatiseringen på grunn av hiv/aids, drar de med seg den negative tankegangen rundt sykdommen i samfunnet for $\varnothing$ vrig og internaliserer den (Rohleder \& Gibson, 2006).

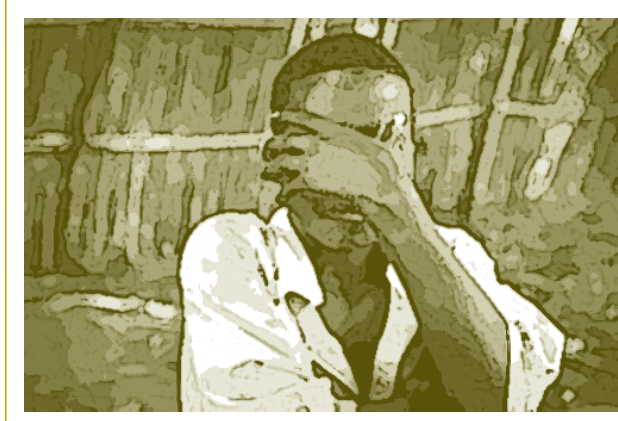

Vi har også et inntrykk av at smittede i det minste $\varnothing$ nsker å ta kontroll over hvordan de skal d $\varnothing$. Det er dessuten viktig å være oppmerksom på sårbarheten hos etterlatte som har mistet sine kjære i hiv/ aids-relaterte selvmord, særlig hvis de er hivpositive selv (Pugh, 1995; Schlebusch, 2005; Sherr, 1995).

Det kliniske bildet kompliseres når personer med immunsvikt får sykdommer knyttet til sentralnervesystemet (CNS). Mange får en kombinasjon av kognitive, motoriske og atferdsmessige endringer som er karakteristiske for subkortikal demens (Schlebusch, 2005; Van Gorp \& Cummings, 1995), aids-demenskompleks (ADC), hiv-encefalopati eller hivrelatert demens (HAD). Studier har vist at hivsmittede med sykdomssymptomer scorer lavere på IQ-tester enn seronegative kontrollpersoner (Van Gorp \& Cummings, 1995). Lettere kognitiv-motorisk svikt (MCMD) kan forekomme i tidlige stadier av hivinfeksjonen (Anderson, 2005; Bartlett, et al., 2004). Sørafrikanske (Schlebusch, Schweitzer \& Bosch, 1998), indiske (Yepthomi, et al., 2006) og andre studier (Anderson, 2005; Lojek \& Bornstein, 2005; Paul, et al., 2002) har rapportert om svekkelse av kognitive funksjoner hos hivpositive personer med fremskreden immunsvikt. De første tegnene på dette kan være psykomotorisk retardasjon, ned- satt finmotorisk hastighet og fingerferdighet, problemer med kognitiv fleksibilitet, konsentrasjonsvansker, hukommelsesproblemer, problemer med visuospatiale ferdigheter/visuell skanning, humørsvingninger, samt uforklarlige anfall. CT- og MRI-skanning viser at det foreligger diffust kortikalt tap av substans med forstørrede furer (sulci) ("valn $\varnothing t$ tt-tegnet") ved aids-demenskompleks (ADC). Det må forskes mer både på hvordan disse neurokognitive komplikasjonene påvirker beslutningsprosessene, og om de kan betraktes som risikofaktorer for selvmordsatferd, samt på spørsmålet om selvmordsatferd kan reduseres som en følge av kognitiv funksjonsbedring etter ARV-behandling. Enkelte studier (Anderson, 2005; Cohen, et al., 2001; Robertson et al., 2004) har beskrevet forbedret neurokognitiv ytelse hos noen hivpositive personer etter intensiv antiretroviral behandling, men det er også rapportert om en $\varnothing$ kning i hivrelaterte forandringer i hjernen (encefalopati) på dødstidspunktet etter $\varnothing \mathrm{kt}$ bruk av ARV-medisiner (Anderson, 2005).

Det er dessuten rapportert om forskjellige psykologiske problemer etter skader (Schweitzer \& Schlebusch, 2001) blant hivpositive idrettsmenn på topp-plan, men vi vet lite om sammenhengen mellom slike vanskeligheter og selvmordsatferd.

\section{Håndtering og forebygging}

Det er ingen grunn til å tro at de forebyggings- og håndteringsstrategiene som brukes ved selvmordsatferd med andre årsaker (Hawton, 2005; Hawton \& Van Heeringen, 2000; Wasserman, 2001), ikke kan komme til nytte også i forbindelse med hiv/aids-relaterte problemer (Anderson, 2005; Bartlett et al., 2004; Van Dyk, 2001). En første utredning av hvilke psykososiale virkninger hiv/aidsinfeksjonen har på smittede personer og deres nærstående er tvingende nødvendig. Den må inkludere en vurdering av mulige neurokognitive komplikasjoner og av psykiske lidelser hos pasienten både før og etter at han/hun ble syk. Angst, depresjon og selvmordstanker kan forekomme i sterk grad mens hivtesting pågår og en stund etterpå, men reduseres hos mange pasienter etter hvert, uavhengig av testresultatet, hvis pasienten avfinner seg med sykdommen og innser at det fin- 


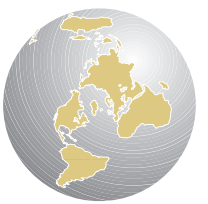

nes behandling (Pugh, 1995). Derfor kan vi ikke få understreket sterkt nok behovet for god rådgivning og terapeutisk st $\varnothing$ tte både f $\varnothing \mathrm{r}$ og etter hivtesting (Van Dyk, 2001). Behandlingen må inkludere psykososial st $\varnothing$ tte og hjelp til stressmestring fordi dette har vist seg å være kritiske faktorer for å klare å leve med sykdommen (Schlebusch, 2000; Schlebusch \& Cassidy, 1995). Hivpositive personer må få hjelp til å se på sykdommen i et rasjonelt, selvutviklende perspektiv istedenfor å gi opp.

Pasientens sosiokulturelle kontekst spiller en viktig rolle for hvordan han/hun takler sykdommen (Noor Mohamed \& Karim, 2000; Schlebusch, 2005). En betydelig andel av afrikanere oppgir $\mathrm{f}$. eks. at de gjerne vil kontakte en tradisjonell healer (Noor Mohamed \& Karim, 2000; Schlebusch, 2005), og derfor er kulturell forståelse og sensitivitet påkrevet.

Sist, men ikke minst, må selvmordsforebygging være med i offentlige opplæringsprogrammer om hiv/aids. Av frykt for diskriminering er mange hivpositive tilbakeholdne med å avsløre at de er smittet, noe som hindrer dem i å få st $\varnothing$ tte fra familien og fellesskapet. Sosio $\varnothing$ konomiske forhold kan spille en stor rolle for mestringsevnen. Veldig mange mennesker i Afrika blir rammet av sykdommen i sine mest produktive år. I mange samfunn er det en ubalanse mellom kjønn og makt - ektemenn (som hovedfors $\varnothing$ rgere) kan forlate sine hivsmittede koner slik at kvinnene blir familiens eneste st $\varnothing$ tte. Dessuten er basisressursene ofte dårlige (for eksempel mat, hus, rent vann, elektrisitet osv.) (Anderson, 2005; Schlebusch, 2005).

\section{Konklusjoner}

Negative oppfatninger og dysfunksjonelle tankem $\varnothing$ nstre hos hivsmittede personer og hos folk flest kan være avgjørende faktorer for hiv/aids-relatert selvmordsatferd. Det er ikke alltid frykten for en potensielt livstruende sykdom i seg selv som utgjør en selvmordsrisiko, men heller hvordan sykdommen og dens følger oppfattes og håndteres (Schlebusch, 2005). Hvis en hivsmittet opplever å bli overlatt til seg selv med sykdommen sin, gir det en følelse av å være forlatt. Dette kan føre til en følelse av håpløshet og lede til en for tidlig $\mathrm{d} \varnothing \mathrm{d}$ ved selvmord.

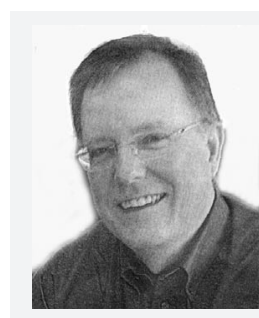

Lourens Schlebusch er professor og leder for Institutt for atferdsfag, Nelson Mandela School of Medicine, Universitetet i Kwazulu-Natal, Durban, Sør-Afrika

\section{Referanser}

Anderson, J.R. (Ed.). (2005). A guide to the clinical care of women with HIV. [Electronic version]. HIV/AIDS bureau U.S. Department of health and human services. http://www.hrsa.gov Bartlett, J.G., Cheever, L.W., Johnson, M.P., \& Douglas, S.P. (Eds.).(2004). A guide to primary care for people with HIV/AIDS. [Electronic version].HIV/AIDS bureau U.S. department of health and human services. http://hab.hrsa.gov/ tools/primarycareguide/ 12.10.2006

Beckerman, N.L. (1995). Suicide in relation to AIDS. Death Studies, 19, 223-34.

Catalan, J. (2000). Sexuality, reproductive cycle and suicidal behaviour. In K. Hawton \& K. van Heeringen (Eds.). The international handbook of suicide and attempted suicide (s.293-307). Chichester: Wiley.

Cohen, R., Boland, R., Paul, R., Tashima, K., Schoenbaum, E., Celentano, D., Schuman, P., Smith, D.K., \& Carpenter, C.C. (2001). Neurocognitive performance enhanced by highly active antiretroviral therapy in HIV-infected women. AIDS, 15, 341-345

Gala, C., Pergami, A., Catalan, J., Riccio, M., Durbano, F., Musicco, M., Baldeweg, T., \& Invernizzi, G. (1992). Risk of deliberate self-harm and factors associated with suicidal behaviour among asymptomatic individuals with human immunodeficiency virus infection. Acta Psychiatrica Scandenavica, 86, 70-5.

Hawton, K. (Ed.). (2005). Prevention and treatment of suicidal behaviour. Oxford University Press.

Hawton, K., \& van Heeringen, K. (Eds.). (2000). The international handbook of suicide and attempted suicide. Chichester: Wiley.

Kelly, B., Raphael, B., \& Judd, F. (1998). Suicidal ideation, suicide attempts and HIV intention. Psychosomatics, 39, 405-15.

Lindegger, G.C., \& Wood, G. (1995). The AIDS crisis: Review of psychological issues and implications, with special reference to the South African situation. South African Journal of Psychology, 25, 1-11.

Lojek, E., \& Bornstein, R.A. (2005). The stability of neurocognitive patterns in HIV infected men: Classification considerations. Journal of Clinical and Experimental Neuropsychology, 27,665-682.

Marzuk, P.M., Tiemey, H., Tardiff, K., Gross, E.M., Morgan, E.B., Hsu, M.A., \& Mann, J.J. (1988). Increased suicide risk of suicide in persons with AIDS. Journal of the American Medical Association, 259, 1,333-7.
Marzuk, P.M., Tardiff, K., Leon, A.C., Hirsh, C.S.,Hartwell, N., Portera, L., \& Iqbal, M.I. (1997). HIV seroprevalence among suicide victims in New York City, 1991-1993. American Journal of Psychiatry, 154 (12), 1720-1725.

Meel, B.L. (2003). Suicide in HIV/AIDS in Transkei, South Africa [Electronic version]. Anil Aggrawal's Internet Journal of Forensic Medicine and Toxicology, 4(1), 1-9.

Ndaba, B. (2005, March 22). I would rather die in my own house. Man kills family, then himself. The Natal Mercury.

Noor Mohamed, S.B., \& Karim, E. (2000). Suicidal ideation and suicide attempts in patients with HIV presenting at a general hospital. In L. Schlebusch \& B.A. Bosch (Eds.). Suicidal behaviour 4: Proceedings of the Fourth Southern African Conference on Suicidology (s.38-48). Durban: Department of Medically Applied Psychology, Faculty of Medicine, University of Natal.

O'Dowd, M.A., Biderman, D.J., \& McKegney, F.P. (1993). Incidence of suicidality in AIDS and HIV-positive patients attending a psychiatry outpatient program. Psychosomatics, 34, 33-40.

Paul, R.H., Cohen, R.A., \& Stern, R.A. (2002). Neurocognitive manifestations of human immunodeficiency virus. CNS Spectrums, 7, 860866.

Perry, S., Jacobsberg, L., \& Fishman, B. (1990).

Suicidal ideation and HIV testing. JAMA, 263 , 679-82.

Pugh, K. (1995). Suicide in patients with HIV infection and AIDS. In L. Sherr (Ed.). Grief and AIDS (s. 45-58). Chichester: Wiley.

Rholeder, P., \& Gibson, K. (2006). 'We are not fresh': HIV-positive women talk of their experience of living with their 'spoiled identity' South African Journal of Psychology, 36, 25-44.

Robertson, K., Robertson, W., Ford, S., Watson, D., Fiscus, S., Harp, A., \& Hall, C.D. (2004). Highly active antiretroviral therapy improves neurocognitive functioning. Journal of Acquired Immune Deficiency Syndrome, 36, 562-566.

Rundell, J.R., Kyle, K.M., \& Brown, G.R. (1992). Risk factors for suicide attempts: Human immunodeficiency virus screening program. Psychosomatics, 33, 24-7.

Schlebusch, L., \& Cassidy, M.J. (1995). Stress, social support and biosychosocial dynamics in HIV/AIDS. South African Journal of Psychology 25, 27-30.

Schlebusch, L., \& Noor Mohamed, S., B. (2005). Suicidal behaviour and HIV/AIDS prevention within the South African context. Paper presented at The XXIII World Congress of the International Association for Suicide Prevention, Durban. Abstract published in Final Programme and Book of Abstracts (s. 29).

Schlebusch, L. (2000). Mind shift: Stress management and your health. Pietermaritzburg: University of Natal Press. 
(Forts. fra s. 32 - HIVIAIDS og risikoen for selvmordsatferd)

Schlebusch, L. (2005). Suicidal behaviour in South Africa. Pietermaritzburg: University of Kwa-Zulu Natal Press.

Schlebusch, L., Schweitzer, G., \& Bosch, B.A. (1998). Psychological considerations in the management of the HIV-infected patient with polytrauma: A case presentation. In L. Schlebusch (Ed.). South Africa beyond transition: Psychological Well-Being (s. 260 -83). Pretoria: Psychological Society of South Africa.

Schweitzer, G., \& Schlebusch, L. (2001). Problems with sport surgery in HIV-positive patients. In N. Maffulli, KM.Chan, R. Macdonald,RM. Malina, AW. Parker (Eds.). Sports Medicine For Specific Ages and Abilities (417-423). London: Churchill Livingstone.

Sherr, L. (1995). The experience of grief: Psychological aspects of grief in AIDS and HIV infection. In L. Sherr (Ed.). Grief and AIDS (s.1-27). Chichester: Wiley.

Siegel, K., and Meyer, I.H. (1999). Hope and resiliance in suicide ideation and behaviour of gay and bisexual men following notification of HIV infection. AIDS Education and Prevention, 11, 53-64. South African Health Review. (2002; 2003/2004). Durban: Health Systems Trust.
Treisman, G.J., \& Kaplin, A.I. (2002). Neurologic and psychiatric complications of antiretroviral agents. AIDS, 16, 1201-1215.

UNAIDS. (2006). Uniting the world against AIDS. Fact sheets. http://www.unaids.org/en/ MediaCentre/ PressMaterials/FactSheets.asp

Van Dyk, A. (2001). HIV/AIDS: Care and counseling; A multidisciplinary approach. Cape Town: Pearson Education.

Van Gorp, W.G., \& Cummings, J.L. (1995).

Neuropsychiatric aspects of infectious disorders. In H.I. Kaplan \& B.J. Sadock (Eds.). Comprehensive textbook of psychiatry (4th ed., s.235-41). Baltimore: Williams and Wilkens.

Wasserman, D. (Ed.). (2001). Suicide: An unnecessary death. London: Martin Dunitz.

Yepthomi, T., Paul, R., Vallabhaneni, S., Kumarasamy, N., Tate, D.F., Solomon, S., \& Flanigan, T. (2006).

Neurocognitive consequences of HIV in Southern India: A preliminary study of clade $\mathrm{C}$ virus. Journal of the International Neuropsychological Society, 12(3), 424-430. 